\title{
Studies on Integrated Nutrient Management and Planting Dates in China Aster for Loose Flower Production
}

\author{
Amita Abrol $^{1 *}$, S. V.S. Chaudhary ${ }^{1}$, S. R. Dhiman ${ }^{1}$, R. K. Gupta ${ }^{2}$ and Rajesh Kaushal ${ }^{3}$ \\ ${ }^{1}$ Department of Floriculture and Landscape Architecture, ${ }^{2}$ Department of Basic Sciences, \\ ${ }^{3}$ Department of Soil Science and Water Management, Dr YSP University of Horticulture and \\ Forestry, Nauni, Solan, Himachal Pradesh-173 230, India \\ *Corresponding author
}

Keywords

China aster,

Nitrogen,

Phosphorous,

Potassium,

Biofertilizers,

Vermicompost,

Planting Dates

Article Info

Accepted:

15 November 2019

Available Online:

10 December 2019

\section{A B S T R A C T}

The present investigation was carried out to standardize integrated nutrient management schedule and planting dates for loose flower production in china aster cv. 'Kamini'. The experiment was laid out in randomized block design (RBD) with 2 planting dates i.e. April and July and 12 treatment combinations i.e. 100\%, 85\% and $70 \%$ NPK along with vermicompost, biofertilizers (Azotobacter + Arbuscular Mycorrhizae fungi) replicated thrice. China aster (Callistephus chinensis (L.) Nees) belongs to family 'Asteraceae' and is native to China. China aster is a symbol of patience and elegance. The species is a hardy annual, commercially grown for loose flowers, which are used in floral decoration, garlands, beds and borders and act as biocolorant. The chemical fertilizers are important sources of nutrients but the indiscriminate use of chemical fertilizers poses the threat of environmental pollution and soil health degradation. Biofertilizers are ready to use live formulation of such beneficial microorganisms which on application to seed, root or soil, mobilize the availability of nutrients by their biological activities. They help in buildup of the soil micro-flora and thereby soil health half dose of nitrogen and whole of the phosphorus and potassium were incorporated in soil one week before planting according to the treatments. The remaining half dose of nitrogen was applied after 30 days of planting. Vermicompost was applied immediately after planting @ $1 \mathrm{~kg} / \mathrm{m}^{2}$. Azotobacter were applied by preparing slurry of $200 \mathrm{~g}$ of the inocula in one litre of $10 \%$ sugar solution as root dip for 500 seedlings. The Arbuscular Mycorrhizae fungal consortia were applied @ $2 \mathrm{~g} /$ plant at the time of planting. The observations on various growth and flowering parameters were recorded and the results revealed that maximum plant height $(72.70 \mathrm{~cm})$, plant spread $(29.77 \mathrm{~cm})$, early blooming $(75.97$ days $)$, number of flower per meter square (471.20), azotobacter count $\left(31.22 \times 10^{-5} \mathrm{cfu} / \mathrm{g}\right.$ of soil) and Arbuscular Mycorrhizae (AM) spore count (206.60 spore count per 50 gram) was observed with $\mathrm{T}_{12}$ i.e. $70 \%$ NPK + Vermicompost + Biofertilizer with April planting. 


\section{Introduction}

China aster [Callistephus chinensis (L.) Nees] belongs to family 'Asteraceae' and is native to China. The basic chromosome number of China aster is 9 and most species are diploid i.e. $2 n=18$. China aster is a symbol of patience and elegance. China aster plants range in height from $15 \mathrm{~cm}$ to about $1.0 \mathrm{~m}$ with pompon flowers about the size of a button to large flower heads having single, double, anemone-flowered, peony-flowered, incurved, quilled or shaggy flower types. The colour range is so great that today China aster is one of the most valuable garden flowers. In all the different types, the colours include pure white, many shades of pink, primrose, pale blue, mauve, purple, dark blue, and scarlet (Randhawa and Mukhopadhyay, 1986). Among annual flower crops, it ranks next to chrysanthemum and marigold (Sindhuja et al., 2018) cultivated mainly by marginal and small farmers of our country. In India, it is grown traditionally for loose and cut flowers, floral decorations, making garlands and venis for hair decoration, bouquets, buttonholes, as bedding plant, making mixed herbaceous border etc. (Khanna et al., 2016).

Biofertilizers are defined as preparations containing living cells or latent cells of efficient strains of microorganisms that help crop plants' uptake of nutrients by their interactions in the rhizosphere when applied through seed or soil. They accelerate certain microbial processes in the soil, which augment the extent of availability of nutrients in a form easily assimilated by plants. Very often microorganisms are not as efficient in natural surroundings as one would expect them to be and, therefore, artificially multiplied cultures of efficient selected microorganisms play a vital role in accelerating the microbial processes in the soil (Murugesan and Prasad, 2006). It is important to produce flowers in a way through which maximum benefits can be obtained from the available nutrient resources which are getting quite costly now-a-days Productivity and quality of the cut and loose flowers along with seed production of China aster can be improved by using high yielding cultivars through improved nutrition. At present, we are not in a position to abandon the use of chemical fertilizers completely, so the best option available is to use these fertilizers in lesser amounts. The eco friendly, economic and easily available biofertilizers are of great help in this context. Biofertilizers are ready to use live formulation of such beneficial microorganisms which on application to seed, root or soil, mobilize the availability of nutrients by their biological activities. They help in buildup of the soil micro-flora and thereby soil health (Singh, 2011).

\section{Materials and Methods}

The present investigation were carried out at the Research Farm of the Department of Floriculture and Landscape Architecture, Dr. Yashwant Singh Parmar University of Horticulture and Forestry, Nauni, Solan, (HP) - 173 230. The experiment was laid out in Randomized Block Design (RBD) with two planting date i.e. April and July, 2018 and 12 treatment combinations 12 treatment combinations i.e. $100 \%, 85 \%$ and $70 \%$ NPK along with vermicompost and biofertilizers (Azotobacter + Arbuscular Mycorrhizae fungi) replicated thrice. The climate of this area, in general, is sub-temperate to sub-tropical and is characterized by mild summers and cool winters. The pure, bold and disease free seeds of China aster cultivar 'Kamini' were used for conducting the studies which were sown in $15-20 \mathrm{~cm}$ raised beds of $1.2 \mathrm{~m}$ width having convenient length containing well rotten farm yard manure (FYM). The experimental field was prepared by ploughing the soil thoroughly up to a depth of $30-35 \mathrm{~cm}$ few days prior to actual date of transplanting. Stones, pebbles 
and plant residues were removed manually. Field was levelled for proper drainage of water. Then, the raised beds of required size of $1 \mathrm{~m} \times 1 \mathrm{~m} \times 15 \mathrm{~cm}$ ( $\mathrm{L} \times \mathrm{B} \times \mathrm{H})$ were prepared and levelled properly.

The chemical fertilizers in the form of Urea, Single super phosphate (SSP) and Muriate of potash (MOP) were applied in different quantities as per the treatment. Vermicompost was applied @ $1 \mathrm{~kg} / \mathrm{m}^{2}$ as per the treatment combinations. For azotobacter application, Slurry was prepared by mixing $200 \mathrm{~g}$ of the inocula in one litre of $10 \%$ sugar solution as root dip for 500 seedlings for 30 minute before transplanting in the field. The AM fungal consortia will be applied @ 2g/plant at the time of planting as per the treatment combinations. The healthy, disease free and stocky seedlings of uniform size and vigour at 5-6 leaf stage were selected and transplanted. The seedlings were planted in raised beds with row to row and plant to plant spacing of $25 \mathrm{x}$ $25 \mathrm{~cm}$ accommodating 16 plants $/ \mathrm{m}^{2}$. Light irrigation was done immediately after transplanting of seedlings. Various intercultural operations like; gap filling, irrigation, pinching, hoeing and weeding were carried out during the course of study as and when required.

\section{Results and Discussion}

An analysis of data presented in Table 1 revealed that maximum plant height $(72.70$ $\mathrm{cm})$ was observed with $\mathrm{T}_{12}(70 \% \mathrm{NPK}+$ Vermicompost + Biofertilizers) and minimum plant height $(59.64 \mathrm{~cm})$ was observed with $\mathrm{T}_{3}$ (70\% NPK). With regards to planting dates, April planting $\left(\mathrm{P}_{1}\right)$ was found more plant height $(90.74 \mathrm{~cm})$ than July planting (42.03 $\mathrm{cm})$. Interactions between treatment and planting dates revealed that maximum plant height $(96.40 \mathrm{~cm})$ was observed in April planting $\left(\mathrm{P}_{1}\right)$ with the application of $\mathrm{T}_{12}(70 \%$
NPK + Vermicompost + Biofertilizers) which was found to be at par with (94.09 and 94.59 $\mathrm{cm}$, respectively) $\mathrm{T}_{1}$ [100\% NPK (Control)] and $\mathrm{T}_{11}(70 \% \mathrm{NPK}+$ Biofertilizers $)$ while it was minimum $(35.42 \mathrm{~cm})$ in $\mathrm{T}_{3}(70 \% \mathrm{NPK})$ from July planting and was statistically to be at par $(36.82 \mathrm{~cm})$ with $\mathrm{T}_{7}$. Similar results were noticed by Kumar et al., (2009) in African marigold; Kirar et al., (2014) in China aster; Manonmani, (1992) in Jasmine cv. Gundumalli.

Maximum plant spread $(29.36 \mathrm{~cm})$ was observed with $\mathrm{T}_{12} \quad(70 \% \quad \mathrm{NPK}+$ Vermicompost + Biofertilizers) and minimum plant spread $(23.25 \mathrm{~cm})$ was observed with $\mathrm{T}_{3}$ (70\% NPK) and was statistically at par with $\mathrm{T}_{2}$ and $\mathrm{T}_{8}$ (25.09 and $24.69 \mathrm{~cm}$, respectively). With regards to planting dates, April planting $\left(\mathrm{P}_{1}\right)$ was found more plant spread $(29.57 \mathrm{~cm})$ than July planting $(22.58 \mathrm{~cm})$. Interactions between treatment and planting was found to be non significant. These results are in confirmation with the works of Ravindra et al., (2013) in China aster and Renukaradhaya (2006) in Carnation (Table 1).

Earliest flowering (75.97 days) was observed with $\mathrm{T}_{12}(70 \% \mathrm{NPK}+$ Vermicompost + Biofertilizers) which was statistically at par with (76.75 and 77.08 days, respectively) $\mathrm{T}_{7}$ and $\mathrm{T}_{11}$ while it was late (84.40 days) observed with $\mathrm{T}_{4}(100 \%$ NPK + Vermicompost). With regards to planting dates, July planting $\left(\mathrm{P}_{1}\right)$ was found earliest blooming (57.77 days) than April planting (100.83 days). Interactions between treatment and planting dates revealed that earliest blooming (54.00 days) was observed in July planting $\left(\mathrm{P}_{2}\right)$ with the application of $\mathrm{T}_{12}(70 \% \mathrm{NPK}+$ Vermicompost + Biofertilizers) which was found to be at par with (54.67, 55.70 and 55.20 days, respectively) $T_{1}, T_{7}$ and $T_{11}$ while maximum days were observed (106.57 days) in $\mathrm{T}_{4}(100 \%$ NPK + Vermicompost) from April planting. 
Table.1 Effect of NPK, biofertilizers and vermicompost on plant height (cm), plant spread (cm) and number of days taken to blooming for loose flower production of China aster cv. 'Kamini'

\begin{tabular}{|c|c|c|c|c|c|c|c|c|c|}
\hline \multirow{2}{*}{$\begin{array}{c}\text { Planting Dates } \\
\text { Treatments }\end{array}$} & \multicolumn{3}{|c|}{ Plant height (cm) } & \multicolumn{3}{|c|}{ Plant spread (cm) } & \multicolumn{3}{|c|}{$\begin{array}{c}\text { Number of days taken to } \\
\text { blooming }\end{array}$} \\
\hline & April & July & Mean & April & July & Mean & April & July & Mean \\
\hline $\mathrm{T}_{2}: 85 \% \mathrm{NPK}$ & 91.47 & 44.57 & 68.02 & 28.94 & 21.24 & 25.09 & 103.40 & 58.87 & 81.13 \\
\hline $\mathrm{T}_{3}: 70 \% \mathrm{NPK}$ & 83.86 & 35.42 & 59.64 & 27.17 & 19.33 & 23.25 & 106.57 & 62.23 & 84.40 \\
\hline $\begin{array}{c}\mathrm{T}_{4}: \mathbf{1 0 0 \%} \mathrm{NPK}+ \\
\text { Vermicompost }\end{array}$ & 89.49 & 39.86 & 64.68 & 28.25 & 23.39 & 25.82 & 102.83 & 58.30 & 80.57 \\
\hline$T_{5}: 100 \%$ NPK + Biofertilizers & 92.50 & 41.43 & 66.96 & 30.32 & 23.64 & 26.98 & 98.63 & 58.83 & 78.73 \\
\hline $\begin{array}{c}\mathrm{T}_{6}: \mathbf{1 0 0 \%} \mathrm{NPK}+ \\
\text { Vermicompost + Biofertilizers }\end{array}$ & 90.08 & 39.10 & 64.59 & 30.42 & 21.04 & 25.73 & 102.33 & 57.93 & 80.13 \\
\hline$T_{7}: 85 \%$ NPK + Vermicompost & 90.20 & 36.82 & 63.51 & 30.44 & 22.07 & 26.25 & 101.80 & 55.70 & 78.75 \\
\hline$T_{8}: 85 \%$ NPK + Biofertilizers & 88.96 & 41.74 & 65.35 & 27.31 & 22.07 & 24.69 & 98.10 & 59.07 & 78.58 \\
\hline $\begin{array}{c}\mathrm{T}_{9}: 85 \% \text { NPK + Vermicompost } \\
\text { + Biofertilizers }\end{array}$ & 88.73 & 44.29 & 66.51 & 28.99 & 22.49 & 25.74 & 100.33 & 60.33 & 80.33 \\
\hline $\begin{array}{c}\mathrm{T}_{12}: 70 \% \mathrm{NPK}+ \\
\text { Vermicompost + Biofertilizers }\end{array}$ & 96.40 & 49.00 & 72.70 & 33.58 & 25.14 & 29.36 & 97.93 & 54.00 & 75.97 \\
\hline Mean & 90.74 & 42.03 & & 29.57 & 22.58 & & 100.83 & 57.77 & \\
\hline $\mathrm{CD}_{0.05}$ & \multicolumn{3}{|c|}{$\begin{array}{lr}\text { Treatment : } & 2.24 \\
\text { Planting dates : } & 0.92 \\
\text { Treatment x Planting da }\end{array}$} & \multicolumn{2}{|c|}{$\begin{array}{l}\text { Treatment } \\
\text { Planting dates } \\
\text { Treatment } x \text { Planting dates }\end{array}$} & $\begin{array}{l}1.84 \\
0.75 \\
\text { NS }\end{array}$ & \multicolumn{2}{|c|}{$\begin{array}{l}\text { Treatment } \\
\text { Planting dates } \\
\text { Treatment x Planting dates }\end{array}$} & $\begin{array}{l}1.34 \\
0.55 \\
1.89\end{array}$ \\
\hline
\end{tabular}

(Biofertilizer: Azotobacter + Arbuscular Mycorrhizae fungi) 
Table.2 Effect of NPK, biofertilizers and vermicompost on number of flower per square meter, Azotobacter count and Arbuscular Mycorrhizae fungi spore count for loose flower production of China aster cv. 'Kamini'

\begin{tabular}{|c|c|c|c|c|c|c|c|c|c|}
\hline \multirow{2}{*}{$\begin{array}{c}\text { Planting Dates } \\
\text { Treatments }\end{array}$} & \multicolumn{3}{|c|}{$\begin{array}{l}\text { Number of flower per } \\
\text { square meter }\end{array}$} & \multicolumn{3}{|c|}{$\begin{array}{c}\text { Azotobacter count }\left(\times 10^{-5} \mathrm{cfu} / \mathrm{g}\right. \\
\text { of soil })\end{array}$} & \multicolumn{3}{|c|}{$\begin{array}{l}\text { Arbuscular Mycorrhizae (AM) } \\
\text { spore count per } 50 \text { gram }\end{array}$} \\
\hline & April & July & Mean & April & July & Mean & April & July & Mean \\
\hline$T_{1}: 100 \%$ NPK (Control) & 494.40 & 394.67 & 444.53 & 9.77 & 11.10 & 10.43 & 23.37 & 19.90 & 21.63 \\
\hline$T_{2}: 85 \%$ NPK & 512.00 & 396.27 & 454.13 & 11.40 & 11.40 & 11.40 & 16.60 & 17.40 & 17.00 \\
\hline $\mathrm{T}_{3}: \mathbf{7 0 \%} \mathrm{NPK}$ & 395.73 & 317.87 & 356.80 & 9.67 & 8.73 & 9.20 & 17.47 & 20.13 & 18.80 \\
\hline $\begin{array}{c}\mathrm{T}_{4}: \mathbf{1 0 0 \%} \mathrm{NPK}+ \\
\text { Vermicompost }\end{array}$ & 486.40 & 364.80 & 425.60 & 9.80 & 9.03 & 9.42 & 20.07 & 19.87 & 19.97 \\
\hline $\begin{array}{l}\mathrm{T}_{5}: 100 \% \mathrm{NPK}+ \\
\text { Biofertilizers }\end{array}$ & 462.40 & 377.07 & 419.73 & 30.43 & 25.63 & 28.03 & 203.33 & 192.90 & 198.12 \\
\hline $\begin{array}{c}\mathrm{T}_{6}: \mathbf{1 0 0 \%} \text { NPK + } \\
\text { Vermicompost + Biofertilizers }\end{array}$ & 450.67 & 356.80 & 403.73 & 31.90 & 27.37 & 29.63 & 208.07 & 197.97 & 203.02 \\
\hline $\begin{array}{c}\mathrm{T}_{7}: \mathbf{8 5} \% \mathrm{NPK}+ \\
\text { Vermicompost }\end{array}$ & 502.93 & 406.40 & 454.67 & 10.03 & 10.57 & 10.30 & 14.33 & 13.97 & 14.15 \\
\hline $\mathrm{T}_{8}: \mathbf{8 5} \% \mathrm{NPK}+$ Biofertilizers & 502.93 & 397.87 & 450.40 & 26.10 & 23.73 & 24.92 & 205.53 & 190.43 & 197.98 \\
\hline $\begin{array}{c}\text { T.9: }_{\mathbf{9}} \mathbf{8 5 \%} \text { NPK + } \\
\text { Vermicompost + Biofertilizers }\end{array}$ & 481.60 & 410.13 & 445.87 & 26.40 & 24.17 & 25.28 & 195.47 & 188.93 & 192.20 \\
\hline $\begin{array}{c}\mathrm{T}_{10}: 70 \% \mathrm{NPK}+ \\
\text { Vermicompost }\end{array}$ & 459.20 & 360.53 & 409.87 & 11.23 & 9.43 & 10.33 & 20.63 & 23.30 & 21.97 \\
\hline$T_{11}: 70 \%$ NPK + Biofertilizers & 502.93 & 404.80 & 453.87 & 27.90 & 27.50 & 27.70 & 206.07 & 197.07 & 201.57 \\
\hline $\begin{array}{c}\mathrm{T}_{12}: 70 \% \text { NPK }+ \\
\text { Vermicompost + Biofertilizers }\end{array}$ & 523.73 & 418.67 & 471.20 & 33.03 & 29.40 & 31.22 & 216.20 & 197.00 & 206.60 \\
\hline Mean & 481.24 & 383.82 & & 19.81 & 18.17 & & 112.26 & 106.57 & \\
\hline $\mathrm{CD}_{0.05}$ & \multicolumn{3}{|c|}{$\begin{array}{l}\text { Treatment : } \\
\text { Planting dates } \\
\text { Treatment x Planting dates }\end{array}$} & \multicolumn{2}{|c|}{$\begin{array}{l}\text { Treatment } \\
\text { Planting dates } \\
\text { Treatment } x \text { Planting dates }\end{array}$} & $\begin{array}{ll}: & 1.76 \\
: & 0.72 \\
: & 2.49\end{array}$ & \multicolumn{2}{|c|}{$\begin{array}{l}\text { Treatment } \\
\text { Planting dates } \\
\text { Treatment x Planting dates }\end{array}$} & $\begin{array}{l}5.47 \\
2.23 \\
7.73\end{array}$ \\
\hline
\end{tabular}

(Biofertilizer: Azotobacter + Arbuscular Mycorrhizae fungi) 
Sheergojri et al., (2013) observed minimum number of days taken for full opening of flower with an application of NPK along with Azotobacter inoculation in dahlia (Table 1).

Maximum number of flower per square meter (471.20) was observed with $\mathrm{T}_{12}$ (70\% NPK + Vermicompost + Biofertilizers) which was statistically at par with (454.67 and 453.87, respectively) $T_{7}$ and $T_{11}$ and minimum flower (356.80) was observed with $\mathrm{T}_{3}$ (70\% NPK). With regards to planting dates, April planting $\left(\mathrm{P}_{1}\right)$ was found more flower (481.24) than July planting (383.82). Interactions between treatment and planting dates was found to be non-significant (Table 2).

Different integrated nutrient treatments influenced azotobacter counts maximum azotobacter colonies $\left(31.22 \times 10^{-5} \mathrm{cfu} / \mathrm{g}\right.$ of soil) was observed with $\mathrm{T}_{12}$ (70\% NPK + Vermicompost + Biofertilizers) which was statistically at par with $\left(29.63 \times 10^{-5} \mathrm{cfu} / \mathrm{g}\right.$ of soil) $\mathrm{T}_{6}$ and minimum azotobacter colonies $\left(9.20 \times 10^{-5} \mathrm{cfu} / \mathrm{g}\right.$ of soil) was observed with $\mathrm{T}_{3}(70 \% \mathrm{NPK})$ and was statistically at par with $\left(10.43,11.40,9.42,10.30\right.$ and $10.33 \times 10^{-5}$ cfu/g of soil) $\mathrm{T}_{1}, \mathrm{~T}_{2}, \mathrm{~T}_{4}, \mathrm{~T}_{7}$ and $\mathrm{T}_{10}$. With regards to planting dates, April planting $\left(\mathrm{P}_{1}\right)$ was found more azotobacter colonies $(19.81 \mathrm{x}$ $10^{-5} \mathrm{cfu} / \mathrm{g}$ of soil) than July planting (18.17 x $10^{-5} \mathrm{cfu} / \mathrm{g}$ of soil). Interactions between treatment and planting dates revealed that azotobzcter colonies $\left(33.03 \times 10^{-5} \mathrm{cfu} / \mathrm{g}\right.$ of soil) was higher in April planting $\left(\mathrm{P}_{1}\right)$ with $\mathrm{T}_{12}$ (70\% NPK + Vermicompost + Biofertilizers) while it was minimum $\left(8.73 \times 10^{-5} \mathrm{cfu} / \mathrm{g}\right.$ of soil) in plants supplied with $\mathrm{T}_{3}(70 \% \mathrm{NPK})$ from July planting $\left(\mathrm{P}_{2}\right)$, which further was statistically at par with $\mathrm{T}_{1}, \mathrm{~T}_{3}, \mathrm{~T}_{4}$ and $\mathrm{T}_{7}$ (9.77, 9.67, 9.80 and $10.03 \times 10^{-5} \mathrm{cfu} / \mathrm{g}$ of soil) of April planting and $\mathrm{T}_{1}, \mathrm{~T}_{2}, \mathrm{~T}_{4}, \mathrm{~T}_{7}$ and $\mathrm{T}_{10}$ (11.10, $11.40,9.03,10.57$ and $9.43 \times 10^{-5} \mathrm{cfu} / \mathrm{g}$ of soil, respectively). These findings are in conformity with Tandon (1992) and Yadav and Raychaudhury (1999) who reported significant increase in microbial population by the addition of organic manures. Similar reports have also been given by Kumar et al., (2003) in China aster and Shashidhara and Gopinath (2002) in Calendula (Table 2).

Maximum AM fungal spore (206.60 per $50 \mathrm{~g}$ of soil) was observed with $\mathrm{T}_{12}$ (70\% NPK + Vermicompost + Biofertilizers) and minimum (14.15 per $50 \mathrm{~g}$ of soil) was observed with $\mathrm{T}_{7}$ (85\% + Biofertilizer) which was ststistically at par with $\mathrm{T}_{2}$ and $\mathrm{T}_{3}$ (17.00 and 18.80 per $50 \mathrm{~g}$ of soil). With regards to planting dates, April planting $\left(\mathrm{P}_{1}\right)$ was found more AM fungal spore $(112.26$ per $50 \mathrm{~g}$ of soil) than July planting (106.57 per $50 \mathrm{~g}$ of soil). Interactions between treatment and planting dates revealed that AM fungal spore (216.20 per $50 \mathrm{~g}$ of soil) was higher in April planting $\left(\mathrm{P}_{1}\right)$ with $\mathrm{T}_{12}$ (70\% NPK + Vermicompost + Biofertilizers) while it was minimum (13.97 per $50 \mathrm{~g}$ of soil) in plants supplied with $\mathrm{T}_{7}(85 \%+$ Biofertilizer) from July planting $\left(\mathrm{P}_{2}\right)$ which was statistically at par with $T_{3}, T_{4}, T_{7}$ and $T_{10}$ in April planting (17.47, 20.07, 14.33 and 20.63 per $50 \mathrm{~g}$ of soil) and $\mathrm{T}_{1}, \mathrm{~T}_{2}, \mathrm{~T}_{3}$ and $\mathrm{T}_{4}$ $(19.90,17.40,20.13$ and 19.87 per $50 \mathrm{~g}$ of soil) in July planting (Table 2).

From the present investigation, it can be concluded that April planting with treatment comprising of $70 \%$ NPK $\left(21 \mathrm{~g}\right.$, each $\left.\mathrm{NPK} / \mathrm{m}^{2}\right)$ along with biofertilizers and vermicompost was found superior regarding loose flower production of China aster cv. 'Kamini'.

\section{References}

Khanna PR, Bohra M, Punetha P and Nautiyal BP. 2016. Studies on the effect of organic manures and PSB on vegetative and floral parameters of China aster (Callistephus chinensis (L.) Nees.) cv. Kamini under mid Hills region of Himalaya. The Bioscan 11(4): 2707-2710.

Kirar KPS, Lekhi R, Sharma S and Sharma R. 2014. Effect of integrated nutrient 
management practices on growth and flower yield of China aster (Callistephus chinensis (L.) Ness) cv. 'Princess'. In: Agriculture: Towards a New Paradigm of Sustainability, pp 234-237. Mishra G C (Ed.). Excellent publishing house, New Delhi.

Kumar D, Singh BP and Singh VN. 2009. Effect of integrated nutrient management on growth, flowering behaviour and yield of African marigold (Tagetes erecta L.) cv. 'African Giant Double Orange'. Journal of Horticultural Sciences 4:134-137.

Kumar P, Raghava SPS and Mishra RL. 2003. Effect of biofertilizers on growth and yield of China aster. Journal of Ornamental Horticulture 6: 85-88.

Manonmani R. 1992. Effect of soil inoculation of Azospirillum and phosphobacteria and graded levels of nitrogen and biofertilizers on growth and yield of Jasmine (Jasmimum sambac Ait) cv. 'Gundumalli'. M.Sc. Thesis, Department of Horticulture, Tamil Nadu Agricultural University, Coimbatore. pp.1-82.

Murugesan R and Prasad G. 2006. Biofertilisers in Ornamental Crops. In: Advances in Ornamental Horticulture (vol.- 1), pp 154181. Bhattacharjee S K (Ed.) Pointer publishers, Jaipur, India.

Randhawa GS and Mukhopadhyay A. 1986. Floriculture in India, pp 358-359. Allied publishers private limited, New Delhi.

Ravindra P, Hanumanthappa M, Hegde JN, Maheshwar KJ and Nagesha L. 2013. Effect of integrated nutrient management on growth, yield and vase life of China aster (Callistephus chinensis (L.) Nees) for coastal Karnataka. Environment and Ecology 31:1104-1106.
Renukaradya S, Pradeepkumar CM, Santhosha HM, Dronachari $M$ and Shashikumar RS. 2006. Effect of integrated system of plant nutrition management on growth, yield and flower quality of carnation (Dianthus caryophyllus L.) under greenhouse. The Asian Journal of Horticulture 6:106-112.

Shashidhara GR and Gopinath G. 2002. Effect of nutrients and bio-inoculants on Calendula. In: Floriculture research trend in India-Proceedings of the national symposium on Indian floriculture in the new millennium, Lal Bagh, Bangalore, pp. 206-208

Sheergojri GA, Neelofar, Rather ZA, Khan FU, Nazki IT and Qadri ZA. 2013. Effect of chemical fertilizers and bio-inoculants on growth and flowering of dahlia (Dahlia variabilies Desf.) cv. Pink Attraction. Applied Biological Research 15: 121-129.

Sindhuja M, Prasad VM and Koradakera V. 2018. Effect of different plant growth regulators and their levels on floral yield and vase life of China aster (Callistephus chinensis (L.) Nees) cv.'Shashank'. International Journal of Current Microbiology and Applied Sciences 7(1): 3391-3396.

Singh SS. 2011. Soil fertility and nutrient management. Kalyani publishers. pp 5166.

Tandon HLS. 1992. Fertilizer and their interpretation with organics and biofertilizers. In: Fertilizers, Organic Manures, Recyclable Wastes and Biofertilizers, (Tandon HLS, Ed.), FDCO, New Delhi. pp. 12-35.

Yadav AK and Raychaudhury S. 1999. Exploiting Biofertilizers in North Eastern Region pp. 26-77.

\section{How to cite this article:}

Amita Abrol, S. V. S. Chaudhary, S. R. Dhiman, R. K. Gupta and Rajesh Kaushal. 2019. Studies on Integrated Nutrient Management and Planting Dates in China Aster for Loose Flower Production. Int.J.Curr.Microbiol.App.Sci. 8(12): 1785-1791. doi: https://doi.org/10.20546/ijcmas.2019.812.214 